\title{
TQM for Information Systems: Are Indian Organizations Ready?
}

\author{
Jamshed Siddiqui \\ Department of Computer \\ Science, Aligarh Muslim \\ University, Aligarh, UP, India
} jamshed faiza@rediffmail.com

\author{
Zillur Rahman \\ Department of Management \\ Studies, Indian Institute of \\ Technology, Roorkee, UA, India
}

yusuffdm@iitr.ernet.in

\begin{abstract}
Conceiving that Total Quality Management (TQM) is a process of embedding quality awareness at every step of production or service while targeting the end customer, we represent it as based on five cardinal principles of top management conviction, customer centric advancements of processes, benchmarking, relentless improvement, and strengthening the employee base. Lodged in the back-drop of increasing awareness for benefit realization through a synergy between Information Systems and TQM this paper examines the readiness of IS managers in India for TQM. Drawing from the results of a questionnaire-based survey conducted amongst IS professionals of some Indian companies it uses multivariate analysis to quantify the extent of top management support for TQM in IS, the extent of benefits realized by TQM, relationship between IS-TQM realized benefits and top management support and relationship between the IS-TQM realized benefits and TQM principles implemented. We conclude that Indian IS managers have a fair understanding of TQM and this shows an upward trend. Top management support is the single most important factor needed for implementation of TQM for IS and better quality of services is presumed to be the most important benefit realized by the firm. The findings fall in compliance with other studies but contribute to research in the unique Indian Market for a potential global investor.
\end{abstract}

Key Words: Total Quality Management (TQM), Information Systems (IS), TQM benefits realized, IS managers, Indian Organisations.

\section{Introduction}

Globalization of market economies has urged corporations in all sectors to concentrate on maintaining a sustainable competitive edge, which is directly, related to the upkeep of quality - both in terms of services as well productivity. An effective model of such a vision of success is Total Quality Management (TQM henceforth), which is a customer centric, set of management policies

Material published as part of this journal, either on-line or in print, is copyrighted by the Informing Science Institute. Permission to make digital or paper copy of part or all of these works for personal or classroom use is granted without fee provided that the copies are not made or distributed for profit or commercial advantage AND that copies 1) bear this notice in full and 2) give the full citation on the first page. It is permissible to abstract these works so long as credit is given. To copy in all other cases or to republish or to post on a server or to redistribute to lists requires specific permission and payment of a fee. Contact Publisher@InformingScience.org to request redistribution permission. that deliver quality (Deming, 1986). It is a management strategy to embed awareness of quality in all organizational processes. It operates within quality circles, which encourage the meeting of minds of the workforce in different departments in order to improve production and reduce wastage.

In this study we have tried to view TQM based on five basic pillars as outlined by (Anderson, Rungtusanatham, \& Schroe- 
der, 1994; Dean \& Bowen, 1994; Waldman, 1994).

1) Top management commitment that works for all quality improvement programs in a very effective manner since the vision of the leaders and policy makers at the top trickles down to the lowest strata of the employee base and henceforth it shows up in organizational productivity and delivery to the end user (Choi \& Behling, 1997).

2) Customer centric advancements of processes which delimit external (product users, suppliers and other components operating in the larger environment) as well as internal customers (fellow employees). Here the customer is involved in designing and assessing products and services and a long-lasting trust worthy relationship with him is built (Lengnick-Hall, 1996).

3) Relentless development by an appetite for risk, changing the decision maker's customer focus, timely and honest self-appraisal, using mistakes and employee cynicism as stepping stone and not obstacle, working within the organizational framework and finally setting goals and deadlines (Lynch \& Werner, 1992) implementing gradual and incremental changes and sometimes even a watershed.

4) Benchmarking involves structured problem solving and identifying processes and finding opportunities for improvements and future developments the tools for which are quality function deployment, Pareto charts, statistical process control charts, cause and effect diagrams and affinity diagrams (Hackman \& Wageman, 1995; Zahedi, 1995).

5) Strengthening the employee base includes enriching the employees with knowledge, learning and training and entrusting them the power to take decisions (Anderson et al., 1994; Shrednick, 1992).

Today the role of top management in improving business standards and customer satisfaction, which also happen to be the essence of TQM, draw from executive decision-making in which it is compulsory to reach out for different information assets (Olszak \& Ziemba, 2006). Data on microchips forms the baseline for many managerial decisions and business strategies. Computerized Information Systems are being used in organizations the world over not only as objects but also as actors (Askenas \& Westelius, 2003). Organizations are being compelled to question and redesign their entire existing traditional operations in a way that uses information technologies and information systems design to serve their business better (Vat, 2004). Integration between strategic business planning and IS planning is considered an important enabler of business - IS alignment (Gottschalk \& Solli-Sæther, 2001; Teo \& Ang 1999). Managers and IS executives undertake variable activities to achieve the objectives of the organization. Changes in both information technology and competition continue to change the role of the IS executive (Gottschalk, 2000; Gackowski, 2005) which increases the customer focus in manufacturing and delivery of product. This renders IS/IT an indispensable element for most organizations liable to TQM.

Application of the five TQM principles applied to IS helps in decelerating wasteful expenditure in technology for the sake of technology (Ayers, 1993). Top management initiatives (Reese, 1995) to think of innovative ways of using IS/IT to develop certain processes has to abandon the stereotype mindset that IS is just a tool for performing several tasks faster and cheaper (Dawson, 1994). IS can be used to measure, identify, monitor and design such product and service attributes that are of value to the customer. This begins with identifying the customers as a first step by the IS professionals (Caroll \& Swatman, 1997; Stylianou, Kumar, \& Khouja, 1997), followed by benchmarking (Criner, 1994; Freedman, 1992) employee enrichment (Prince, 1993; Shrednick, 1992) and striving for continuous growth. There are many benefits of TQM for IS if the above principles are successfully implemented and in the long run these may also be potentially significant ones (Carroll \& Swatman, 1997; Pearson, McCahon, \& Hightower, 1995). 
In the concluding period of the last millennium as India opened itself to the liberal market economy, after several decades of stiff regulations in business strategy, the manufacturing and service industries have made a significant contribution to the phenomenal economic growth made by the nation in the global market. However it has been realized that the national market has suffered deterioration in some areas due to a lack of competitive sustainability. For example the influx of foreign goods - Chinese locks for instance, has caused a serious blow to the native lock industry. Similarly in many other sectors the Indian products and services are losing out to competition with imported stuff, as they are either more cost effective or better in quality. Further more as the Indian customer becomes more and more brand savvy - largely owing to the media exposure, quality consciousness is doomed to increase and if quality issues in the Indian industry are not addressed in time, competition might result in elimination.

This new wave of quality awareness has had an impact on business operations in India forcing the industry to take a paradigm towards being high-quality producers rather low-cost producers. As a result lately Indian firms have increased investment on quality management imperatives rather cost-cutting alone, as they have realized that competition solely on the basis of cost is extremely difficult. Now that some firms have awakened to the need of quality improvement and adopted TQM as the remedial measure it is time to evaluate the success of their achievements and quantify the goals realized by them in practicality.

\section{Rationale}

In the present study an attempt has been made to quantify the empirical aspects of TQM for the IS of organizations. It was reckoned by the perusal of past publications that organizations have had unqualified success in pursuing quality management on account of multiple failures such as compound focus of programs leading to dilution of results, assuming that action and result come in a package and lack of stepwise appraisal of schemes and achievements. Also it has been felt that IS professionals are still hesitant and apprehensive about adopting TQM in software engineering as a consequence of a general misunderstanding of its practices and principles (Zadrozny \& Tumanic, 1992). A special emphasis on IS in this paper is aimed at clarifying upon these misunderstandings. We also wish to elaborate upon the ways in which IS can make use of TQM in India. Given the long drawn experience of Indian industry with TQM in the field of IS this study has tried to evaluate the extent of their relationship in terms of awareness and utility. Further we also suggest that the results are quite generalist and they can be applied to the markets and industries of other countries as well particularly those which have made a venture in the IS sector because information is a valuable asset for almost every organization. All organizations are making use of information and related systems to enhance quality and services to attain a firm grip over the market share.

\section{Hypothesis and Objectives}

Based on the philosophy of TQM and its applicability to IS functions we drew the hypothesis that IS managers in Indian firms accede to the application of TQM principles for IS functions to realize empirical goals. The following specific objectives were set to defend this hypothesis:

1. The awareness usage and length of experience of TQM in IS

2. The extent of top management support for TQM in IS

3. The extent of benefits realized by TQM in IS

4. The extent to which the TQM principles are applied to IS

5. Relationship between IS-TQM realized benefits and top management support

6. Relationship between the IS-TQM realized benefits and TQM principles implemented. 


\section{Methodology}

\section{Data Collection}

Data collection was done by mail survey questionnaires. 300 Indian companies assumed to be making use of TQM in their Information Systems department were selected for the survey. Prior to this it was not confirmed whether the firms had implemented TQM or otherwise. The conceptual responses here pertained to an exploration of the spread of TQM and helped determine its extent and impact on the IS of a company. However, much could not be derived on the specific methods adapted by a particular company for exploiting TQM in production or use of IS to meet their customers with service or manufacturing because competition in the corporate sector prevents companies from divulging their corporate strategies specially those that our adopted for enhancing their customer base.

The list was procured from the BT-500 list of top Indian companies published by Business Today. The data set was intended to represent a large variance in their annual turnovers, worth of assets, IS budgets and the segment of the industry to which they catered. Addressed to the top executive In charge of the IS department the survey questionnaire was mailed to each of the organizations. The respondent organizations and there IS departments exhibited great variance. A wide array of business areas such as insurance, banking, software, manufacturers etc. were represented. They also varied in size (annual sales and number of employees) and IS budgets or IS employees in particular. The received bulk of responses also represented this spectrum chosen for the study.

Similar studies conducted in various sectors abroad (Ahire, Golhar, \& Waller, 1996; Cheon \& Stylianou, 2001; Pearson et al., 1995) were consulted and due modifications were done to suit the Indian firms and Information Systems departments to design a questionnaire that could derive information and opinions from organizations. The questionnaire had five sections; these solicited information about the organization and respondent demographics, the potential and realized benefit derived from TQM, the respondent's understanding of the basic TQM concepts/tools, the perceived utility of TQM concepts / tools within the internal environment. The items were written in the form of statements to which the respondents responded using a seven-point Likert-type scale (ranging form strongly disagree to agree).

A follow up questionnaire was mailed to those who did not respond up to eight weeks and another follow up was sent after a no-reply for twelve weeks. Out of the total questionnaires dispatched only 134 came back with responses however after sorting out duly it was found that 14 of them were rendered unreliable due to ambiguous answers. Finally 120 responses $(40 \%)$ were included for analysis and drawing an inference.

\section{Data Analysis}

Usable responses were sorted out from the bulk of responses received. Non-response bias was checked by comparing the answers provided by the first respondents with those provided by respondents following the second and third mailing (Fowler \& Jeffs, 1998). This could be done safely because analysis indicated that there is no significant difference at the level of 0.05 among these three groups with respect to their total sales, number of employees, IS budgets and number of IS employees. As an added advantage this lack of non-response bias implies that the results obtained from this study sample can be implied to a larger set of population too.

The one-tailed t-tests were used to determine variations in the organizations surveyed as the organizations were grouped into two classes of organizational demographics. Due to the large number of research variables and sampling units one-way ANOVA was found most suitable to test which concepts / tools and benefits the IS managers believed were important for TQM. When 
significant differences existed in the importance IS managers placed on the TQM concepts / tools or the benefits realized, to examine these differences Tukey's Honestly significant Difference (HSD) were calculated to determine if differences in these concepts /tools and benefits realized. Test of goodness of fit was used to test the relationship of TQM principles and its benefits realized. Further multiple regression analysis was performed to identify the key exploratory research variables related to quantify the effect of TQM principles on organizational benefits.

\section{Results}

The organizations surveyed differed in many organizational demographics. Analysis suggests that there were significant differences between the companies' annual sales, number of employees, IS budgets and sector of industry to which they belonged (Table 1). While $40 \%$ of the companies surveyed belonged to the manufacturing sector $60 \%$ were performing in the service sector of the industry. 20\% firms had recorded annual sales up to 200 million INR, 30\% had annual sales above 650 million INR and the remaining 50\% had recorded annual sales between 200 million and 650 million INR. These sales were achieved with an IS budget allocation of less than 2 million in $55 \%$ companies, up to 6.5 million in $27 \%$ companies and more than 6.5 million in only $18 \%$ firms surveyed. Similarly, statistically significant differences were found in the number of employees - which varied between less that $500(12 \%)$ to more than $3500(15 \%)$ with the majority (73\%) of companies having between 500 to 3500 employees, and the number of IS employees in the company - $20 \%$ companies had more than 45 IS employees and $30 \%$ had less than 15 IS employees, while $50 \%$ companies had employed between 15 to 45 people in there is departments.

Table 1: Variations in organizational demographics of the organizations surveyed

\begin{tabular}{|l|l|l|l|l|}
\hline $\begin{array}{c}\text { Organization } \\
\text { demographics }\end{array}$ & Type & \% Value & t-statistic & P - value \\
\hline \multirow{2}{*}{ Industry } & Manufacturing & 40 & 12.345 & .000 \\
\hline & Finance & 60 & & .001 \\
\hline \multirow{2}{*}{ Annual sales } & $>650$ million & 30 & 43.177 & .001 \\
\hline & $<200$ million & 20 & & .002 \\
\hline \multirow{2}{*}{ Employees } & $>3500$ & 15 & 21.796 & .000 \\
\hline \multirow{2}{*}{ IS budget } & $<500$ & 12 & & .000 \\
\hline \multirow{2}{*}{ IS employees } & $<2$ million & 55 & 16.289 & .000 \\
\hline & $>6.5$ million & 18 & & .003 \\
\hline & $>45$ & 20 & 47.446 & .000 \\
\hline & $<15$ & 30 & & .000 \\
\hline
\end{tabular}

\section{Comprehension Level of TQM amongst IS Managers}

Table 2 illustrates that all the 120 managers who responded to the survey had heard of TQM. However, their levels of familiarity and awareness about the process varied from a range of 3.3\% percent (very little) to $37.5 \%$ (somewhat). This indicates that a larger portion of the group had quite a fair idea of the TQM principles. It further reveals that their perception about the impact of TQM on IS was also on the positive side i.e. almost two-third of the group believed that TQM contributed positively towards IS improvement. 
Table 2: Comprehension level of TQM amongst IS managers

\begin{tabular}{|c|c|c|c|c|c|}
\hline \multicolumn{2}{|c|}{ Comprehension level } & \multicolumn{2}{|c|}{ Frequency } & \multicolumn{2}{|c|}{ Percent } \\
\hline \multirow{2}{*}{$\begin{array}{l}\text { Heard } \\
\text { of TQM }\end{array}$} & Yes & 120 & \multirow{2}{*}{120} & 100 & \multirow{2}{*}{100} \\
\hline & No & 0 & & 0 & \\
\hline \multirow{5}{*}{$\begin{array}{c}\text { Familiarity with } \\
\text { TQM } \\
\text { Principles }\end{array}$} & Very much & 15 & \multirow{5}{*}{120} & 12.5 & \multirow{5}{*}{100} \\
\hline & Much & 30 & & 25 & \\
\hline & Somewhat & 45 & & 37.5 & \\
\hline & A Little & 26 & & 21.6 & \\
\hline & Very Little & 4 & & 3.3 & \\
\hline \multirow{5}{*}{$\begin{array}{c}\text { Concept of } \\
\text { Effect of TQM } \\
\text { On IS }\end{array}$} & Very Much & 14 & \multirow{5}{*}{120} & 11.7 & \multirow{5}{*}{100} \\
\hline & Much & 36 & & 30 & \\
\hline & Moderate & 42 & & 35 & \\
\hline & A Little & 28 & & 23.3 & \\
\hline & Very Little & 0 & & 0 & \\
\hline
\end{tabular}

\section{Length of TQM in IS Experience}

Responses depict (Table 3) that all the 120 respondent firms - 100\%, were making use of TQM in IS, however a miniscule (3\%) of them have a long drawn experience (more than five years) of TQM in IS. The largest percentage (43\%) is of those firms, which have been exploiting TQM for more than a year but less than three years. About $21 \%$ are senior to this group by one or two years and $32.5 \%$ are yet to mature to a years' experience.

Table 3: Length of TQM in IS experience

\begin{tabular}{|c|c|c|}
\hline Length (year) & Frequency & Percent \\
\hline Less than 1 & 39 & 32.5 \\
\hline 1 to 3 & 52 & 43.33 \\
\hline 3 to 5 & 25 & 20.83 \\
\hline Above 5 & 4 & 3.33 \\
\hline Total & $\mathbf{1 2 0}$ & $\mathbf{1 0 0}$ \\
\hline
\end{tabular}

\section{TQM Benefits for IS}

As already mentioned in the methodology respondents were asked to rate the TQM benefits for IS on a seven point Likert-type scale ranging from disagree to strongly disagree. Analysis revealed that most respondents felt that the most desirable benefit of TQM for IS, is increased quality of services and products followed by a greater productivity of IS professionals. 
Table 4: Benefits of TQM for IS

\begin{tabular}{|l|c|c|c|}
\hline \multirow{2}{*}{ TQM Benefits } & \multicolumn{3}{|c|}{ Tukey's HSD } \\
\cline { 2 - 4 } & Mean & $\begin{array}{c}\text { Standard } \\
\text { Deviation }\end{array}$ & t-statistic \\
\hline Cost cutting on maintenance of applications & 4.6333 & 1.3014 & $72.4^{*}$ \\
\hline Increased IS management control & 5.2175 & 1.0041 & $59.8^{*}$ \\
\hline Superior quality of services & 5.3245 & 1.1147 & $52.3^{*}$ \\
\hline Greater customer satisfaction & 5.2126 & 1.1834 & $58.6^{*}$ \\
\hline Enhanced IS professional productivity & 5.0999 & 1.0738 & $69.9^{*}$ \\
\hline Slashed time consumption on production & 4.2133 & 1.1873 & $76.4^{*}$ \\
\hline Improved quality of products delivered & 5.2526 & 0.9768 & $61.3^{*}$ \\
\hline Optimization of human resource use & 5.0106 & 1.1867 & $68.1^{*}$ \\
\hline Flexibility in reaching out to customer & 5.1349 & 1.2013 & $65.2^{*}$ \\
\hline
\end{tabular}

*Significant at 0.01

\section{Implemented TQM Principles}

The questionnaire contained a Likert-type seven point scale ranging from disagree to strongly agree regarding the implementation of the five principles of TQM in IS. The respondents measured the success achieved in this implementation on the scale. It was found after analyzing the opinions that the most effectively used TQM principles were those of Customer centric advancements and employee enrichment by strengthening the employee base (See Table 5). However, when implemented to IS other TQM principles also did fairly well.

Table 5: Degree of implementation success with TQM principles in IS

\begin{tabular}{|l|c|c|c|}
\hline \multirow{2}{*}{$\begin{array}{l}\text { Implemented TQM } \\
\text { Principles }\end{array}$} & \multicolumn{3}{|c|}{ Tukey's HSD } \\
\cline { 2 - 4 } & Mean & Standard Deviation & t-statistic \\
\hline Conviction of top management & 4.8563 & 1.1432 & $87.0^{*}$ \\
\hline Customer centric advancements & 5.3675 & 1.1046 & $57.8^{*}$ \\
\hline Relentless improvement & 4.8823 & 1.2768 & $85.6^{*}$ \\
\hline Strengthening of employee base & 5.2363 & 1.1134 & $62.4^{*}$ \\
\hline Benchmarking & 4.7342 & 1.3391 & $79.1^{*}$ \\
\hline
\end{tabular}

*Significant at 0.01

A limitation of the results in Table 4 and 5 are the high mean values and little difference between the means. In this case we can say that one category is different from another by the interpretations of the Post hoc t-statistic revealed by performing ANOVA.

\section{Relationship between Top Management and TQM Benefits}

Of the 120 responses received $58 \%(\mathrm{n}=70)$ felt that TQM for IS receives strong support from the top management in their firm and $42 \%(n=50)$ in their firms TQM for IS receives somewhat less or very little support from the top management. Relationship analysis was done by subdividing 
the respondents' opinions into two categories - high for much and very much; and low for little and very little. Subjecting to the test of goodness of fit revealed that there is a significant difference between benefits accrued from TQM through strong management support and those of less management support (See p value in Table 6). Hence it can be concluded that top management commitment to TQM is a decisive factor of TQM benefits for IS organizations.

Table 6: Relationship of Top Management Support and TQM Benefits

\begin{tabular}{|c|c|c|c|c|}
\hline Variable & $\begin{array}{c}\text { Top Manage- } \\
\text { ment Support }\end{array}$ & Mean & T-Value & p-value \\
\hline $\begin{array}{c}\text { TQM Bene- } \\
\text { fits }\end{array}$ & $\begin{array}{c}\text { High }(n=70) \\
\text { Low }(n=50)\end{array}$ & $\begin{array}{c}5.6234 \\
4.1867\end{array}$ & 3.186 & .0023 \\
\hline
\end{tabular}

\section{Implementation of TQM Principles and Benefits Realized}

The simple regression analysis was performed to test the significance of the relation ship of each TQM principle implemented and TQM benefits realized. The key motive of each test was to see if the simple linear equation is significant or the observed frequencies are just a matter of chance. Analysis revealed that each equation was significant at 0.05 level with $R^{2}$ ranging from 0.30 to 0.35 .

The results of all possible regression analysis shows that two independent variables provide the key impressions for TQM benefits of IS organizations - these are customer centric advancements and support of top management. Therefore from table 6 we may conclude that the successful implementation of TQM principles and realization of benefits relies on these two important factors of critical value. Hence the null hypothesis that the frequencies of different observations for TQM principle implementation are chance observations and there is no working mechanism behind them is rejected.

Table 7: Relationship between Implemented TQM Principles and TQM Benefits

\begin{tabular}{|l|c|c|c|}
\hline \multirow{2}{*}{ TQM Principles Implemented } & \multicolumn{2}{|c|}{ TQM Benefits Realized } \\
\cline { 2 - 4 } & $\begin{array}{c}\text { T for } \mathbf{H}_{\mathbf{0}}: \\
\text { Parameter }=\mathbf{0}\end{array}$ & P-value & $\mathbf{R}^{\mathbf{2}}$ \\
\hline Conviction of top management & 4.476 & .0001 & 0.3527 \\
\hline Customer centric advancements & 4.378 & .0002 & 0.3271 \\
\hline Relentless improvement & 3.324 & .0005 & 0.3043 \\
\hline Strengthening of employee base & 4.276 & .0002 & 0.3297 \\
\hline Benchmarking & 2.547 & .0328 & 0.1189 \\
\hline
\end{tabular}

Although the individual variables are significant, since there is a serious co linearity among the independent variables a further multiple regression analysis is performed to identify the key exploratory variables among the five factors (Table 8). Also it has been indicated that biased results from multiple regression analysis begin to creep in at correlations above 0.5 (Cheon \& Stylliannou, 2001). 
Table 8: Key exploratory variables among the five factors

\begin{tabular}{|l|l|l|l|l|l|l|}
\hline $\begin{array}{c}\text { TQM } \\
\text { Principle }\end{array}$ & $\begin{array}{l}\text { TQM } \\
\text { Benefit }\end{array}$ & CTM & CCA & RI & SEB & BM \\
\hline CTM & $0.666^{*}$ & & & & & \\
\hline CCA & $0.621^{*}$ & $0.410^{*}$ & & & & \\
\hline RI & $0.566^{*}$ & $0.669^{*}$ & $0.614^{*}$ & & & \\
\hline SEB & $0.581^{*}$ & $0.565^{*}$ & $0.675^{*}$ & $0.762^{*}$ & & \\
\hline BM & $0.403^{*}$ & $0.512^{*}$ & $0.426^{*}$ & $0.573^{*}$ & $0.569^{*}$ & \\
\hline
\end{tabular}

${ }^{*}$ Significant at 0.01

\section{Discussion}

Before we discuss the results obtained by the research methodology adopted we must also clarify the limitations of the data collection and its analysis. The results have been promulgated on the basis of opinions expressed by one individual of a firm because in one organization only one questionnaire was mailed. Hence any difference of opinion between individuals of the same company has not found scope of representation as well as multiple opinions from a firm have not been entertained. Maybe a study with such design could give wider representation to the management of the company. For any questionnaire-based survey it is impossible to completely eliminate the bias from respondents while filling the spaces because data is opinion based and not numerical based. Another limitation of this study is that we assumed at the beginning of the commencement that the respondents have a fair understanding of TQM philosophies and hence we did not include any statements that test the comprehension level of the respondents about TQM. However these lacunae in the study leave future ground for explorations and research on the subject.

On the basis of the study results we might state that TQM for IS organizations is catching up fast amongst Indian organizations because 100\% respondents had heard of TQM. Also the greater portion of the sample (more than two thirds) was familiar with TQM and were convinced that it has a good impact for IS organizations. Further detailed quest reveals that organizations In India are adopting TQM readily as most of them have several years of experience with TQM for IS. We may argue based on this finding that in future more and more companies will subscribe to the philosophies of TQM. This readiness may be attributed to the benefits of TQM realized by IS functions. The most common ones being greater customer satisfaction, increased productivity of IS personnel and enhanced quality of services and products. However the other benefits such as cost and time cutting on production and optimization of human resources too are rated well as TQM benefits. This shows TQM is taken in a good light for the allover performance of the company. Amongst all the TQM principles described earlier the best implementation success was received in the principles of customer centric advancements and employee enrichment by strengthening the employee base. This shows that TQM has the capability to entice the primary as well as the secondary customer. In depth relationship analysis of TQM implementation and TQM benefits depicts that the most important factor on which TQM implementation benefits rely is the top management support. Most of the respondents felt the degree of success achieved in implementing TQM has a strong relationship with the commitment and support provided by the top management, as it is the fountainhead for all key policies of the firm.

Finally it was concluded that the key influencers of TQM benefits were customer centric advancements and top management's support. Therefore, the successful implementation of TQM depends on these two key factors. Earlier also many authors have realized the importance of the top management support for TQM and recommended the following practices to be embraced for good commitment to TQM (Cortada, 1995). a) setting strategic visions and conveying them to 
employees, b) preserving high standards of measurable quality c) modeling the way to customer end user focus, c) fostering a world of continuous improvement and d) empowering the employee base by encouraging teaming, initiatives and individual accomplishments. Similarly to assure customer centric advancements to facilitate better TQM implementation steps have been suggested. (Pearson, McCahon, \& Hightower, 1996 ) has outlined them as a) identify the real IS customer; b) understand their expectations and c) commit to the flagship processes critical to the success in meeting these expectations.

Since this study was conducted in India when almost the entire market had adopted itself to globalization it will not be out of place to suggest that the research findings also have global applicability apart from being of use to the academics and business environment of India. If not to the well-advanced west at least for neighboring countries such as Pakistan, Bangladesh, Nepal, Maldives, Sri Lanka, Bhutan in the SAFTA (South Asian Free Trade Association) these findings are well applicable because they have a similar cultural and traditional milieu. In an unexaggerated form the applicability may even radiate to the not so far off Middle East and the Polynesia. When the study was compared with other published work similarities were discovered in the results. For example (Howard \& Foster, 1999; Hua, Chin, \& Xu, 2000; Rao \& Raghunathan, 1997; Sohal, 1998) also support the importance of top management commitment for TQM implementation. Our findings are also in agreement with the publication of (Pearson et al., 1995) with regard to the extent of TQM awareness amongst IS professionals.

Dahlgaard, Kristensen, Kanji, Juhl, and Sohal (1998), however, imply that a significant gap remains between the success with TQM for IS in the west and the east. But there too additional emphasis on top management commitment and employee strengthening by on the job training and education is stressed. If the gap is only in the extent of success and adaptability and not regarding a basic philosophy or trend then it is only matter of time when business traditions in the east too will incorporate TQM as an integral element as in the west. The Indian economy has taken an unprecedented paradigm shift towards the open market system in recent and it is showing an elephantine growth that has diverted the attention of the global community. Moreover, the country is trying its bets to attract foreign investment. Since this is a new market for many owing to the uniqueness of India as a nation and its strong cultural constraints, it is reasonable for investors to have first-time doubts.

This paper contributes the knowledge to the world that in India conditions are not any different and hence it does not provide an altogether new business environment where implementation of TQM for an organization would mean some thing novel as compared to the rest of the world. The clear managerial implication of this study is for business executives looking at business standard improvement with a customer focus and hence contemplating on implementing TQM. The study can provide insights to managers regarding setting their priorities based on the principal components while relating them to benefits. For instance a manager facing the issues such as overhauling IS aspects for TQM may make choices based on the results of this study.

However to reduce the limitations mentioned above further detailed research is recommended meanwhile customer centric advancements and top management commitment are highlighted as the key variables that influence TQM which accrues benefits such as customer satisfaction and cost cutting for IS organizations.

\section{References}

Ahire, S., Golhar, D., \& Waller, M. (1996). Development and validation of implementation constructs. Decision Sciences, 27(1), 23-56.

Anderson, J., Rungtusanatham, M., \& Schroeder, R. (1994). A theory of quality management underlying the Deming management method. Academy of Management Review, 19(3), 472-509. 
Askenas, L. \& Westelius, A. (2003). Five roles of an information system: A social constructionist approach to analyzing the use of ERP systems. Informing Science, 6, 209-220. Available at http://inform.nu/Articles/Vol6/v6p209-220.pdf

Ayers, J.B. (1993).Total quality management and information technology: Partners for profit. Information Strategy. The Executive Journal, 9(3), 26-31.

Carroll, J., \& Swatman, P. (1997). Total quality management for information systems: The Australians experience. Proceedings of 8th Australian Conference on Information Systems.

Cheon, M.J. \& Stylianou, A.C. (2001). Total quality management for information systems: An empirical investigation. Journal of Global Information Technology Management, 4(4), 3-25.

Choi, T.Y. \& Behling, O.C. (1997). Top managers and TQM success: One more look after all these years. Academy of Management Executive. 11(1), 37-47.

Cortada, J.W. (1995). TQM for information systems management. New York: McGraw-Hill.

Criner, J.C. (1994) Benchmarking data processing installation. Capacity management review, 22(3), 1-6.

Dahlgaard, J.J., Kristensen, K., Kanji, G.K., Juhl, H.J., \& Sohal, A.S. (1998). Quality management practices: A comparative study between East and West. International Journal of Quality \& Reliability Management, 15(8/9), 812-826.

Dawson, S.P. (1994). Continuous improvement in action: Applying quality principles to software. Information Systems Management, 11(1), 31-39.

Dean, J.W. \& Bowen, D.E. (1994). Management theory and total quality: Improving research and practice through theory development. Academy of Management Review, 19(3), 392-418.

Deming, W.E. (1986), Out of the crisis. Cambridge: MIT Press.

Fowler, A. \& Jeffs, B. (1998). Examining information systems outsourcing: A case study from the United Kingdom. Journal of Information Technology. 13(2), 111-126.

Freedman, D. (1992). Those who can teach. CIO, 5(17), 46-51.

Gackowski, Z. J. (2005). Informing systems in business environments: A purpose-focused view, Informing Science Journal, 8, 101-122. Available at http://inform.nu/Articles/Vol8/v8p101-122Gack.pdf

Gottschalk, P. (2000). Information systems executives: The changing role of new IS/IT leaders. Informing Science, 3(2), 31-39. Available at http://inform.nu/Articles/Vol3/v3n2p31-39.pdf

Gottschalk, P. \& Solli-Saether, H. (2001). Differences in stage of integration between business planning and information systems planning according to value configurations, Informing Science, 4(1), 1-10. Available at http://inform.nu/Articles/Vol4/v4n1p001-010.pdf

Hackman, J.R. \& Wageman, R. (1995). Total quality management: Empirical, conceptual, and practical issues. Administrative Science Quarterly, 309-342.

Howard, L.W., \& Foster, S.T. (1999). The influence of human resource practices on empowerment and employee perceptions of management commitment to quality. Journal of Quality Management, 4(1), 532.

Hua, H., Chin, K.S., \& Xu, Y. (2000). An empirical study on quality management practices in Shanghai manufacturing industries. Total Quality Management, 11(8), 1111-1112.

Lengnick-Hall, C.A. (1996). Customer contributions to quality: A different view of the customer-oriented firm. Academy of Management Review, 21(3), 791-824.

Lynch, R.F. \& Werner, T.J. (1992). Continuous improvement. Atlanta, GA: Qual Team Inc.

Olszak, C.M. \& Ziemba, E. (2006). Business intelligence systems in the holistic infrastructure development supporting decision making in organizations, Interdisciplinary Journal of Information, Knowledge and Management, 1, 47-58. Available at http://ijikm.org/Volume1/IJIKMv1p047-058Olszak19.pdf

Pearson, J.M., McCahon, C.S., \& Hightower, R.T. (1995). Total quality management: Are information system managers ready? Information \& Management, 29, 252-263.

Pearson, J.M., McCahon, C.S., \& Hightower, R.T. (1996). A framework for the introduction of total quality management into the IS department. Journal of Computer Information Systems, 37(2), 21-26. 
Prince, E.T. (1993). Human factors in quality assurance. Management, 10(3), 78-80.

Rao, S.S., \& Ragunathan, T.S. (1997) A comparative study of quality practices and results in India, China and Mexico. Journal of Quality Management, 2(2), 235-249.

Reese, S. (1995). Sharpening your competitive edge with information systems. Industrial Management, 37(1), 13.

Shrednick, R.H. (1992). The quality quagmire. CIO, 6(3), 28-31.

Sohal, A.S. (1998). Assessing manufacturing/quality culture and practices in Asian companies. International Journal of Quality \& Reliability Management, 15(8/9), 920-930.

Stylianou, A.C., Kumar, R.L., \& Khouja, M.J. (1997). Total quality management-based systems development process. DATABASE for Advances in Information Systems, 28, 59-71.

Teo, T. S. H. \& Ang, J. S. K. (1999). Critical success factors in the alignment of IS plans with business plans. International Journal of Information Management, 19, 173-185.

Vat, K.H. (2004). On the idea of organization transformation: The IS/IT design challenge in systems thinking, Issues in Informing Science and Information Technology, 1, 941-950. Available at http://articles.iisit.org/120vat.pdf

Waldman, D.A. (1997). The contributions of total quality management to a theory of work performance. Academy of Management Review, 19(3), 510-536.

Zadrozny, M.A. \& Tumanic, R.E. (1992). Zero-defects software: The total quality management approach to software engineering. CIO, 4(4), 10-16.

Zahedi, F. (1995). Quality information systems. Danvers, MA: Boyd \& Fraser.

\section{Biographies}

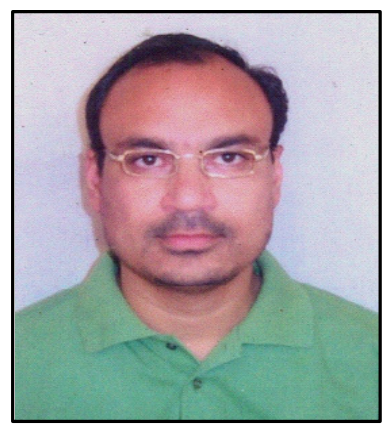

J. Siddiqui is a Senior Lecturer at Computer Science Department, Aligarh Muslim University, Aligarh, India. He holds Masters in Computers Science and currently pursuing Ph. D. in Information Systems from Indian Institute of Technology Roorkee, India.

His special interests include Information Systems, MIS, Systems Analysis \& Design, Knowledge Management Systems, E-Business and Decision Support Systems.

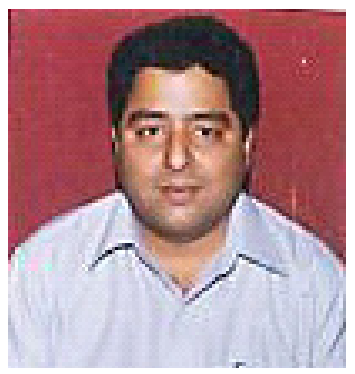

Dr. Z. Rahman is Assistant Professor in the Department of Management Studies, at Indian Institute of Technology Roorkee, India. Dr Rahman was the recipient of the Emerald Literati Club Highly Commended Award in 2004. One of his papers was The ScienceDirect TOP 25 HOTTEST ARTICLE within the journal for the period Oct-Dec 2004.

His teaching and research interests are in the area of International Business, Information Systems, Marketing, and Strategic Management. Dr Rahman's work has been published and cited in various international journals including Management Decision, Managing Service Quality, International Journal of Information Management, Industrial Management and Data Systems, European Business Review, Journal of Database Marketing and Customer Strategy Management, International Journal of Service Industry Management, Information Systems Journal, Decision Support Systems, Journal of Business and Industrial Marketing, and International Journal of Computer Integrated Manufacturing. 